\section{Brianna Perry}

Brianna Perry is a visual artist, writer, and poet, originally born in Chicago, Illinois. She is interested in the intersection between studying and practicing black cultural production. By submitting to this journal, she hopes to be in conversation with a larger community of thinkers who are reckoning with blackness in their creative and scholarly practices.

\section{If Tou're Woke You Dig It}

Contrary to the general consensus that the origins of "woke" lie in the 2008 Erykah Badu song "Master Teacher", the genesis of "woke" can be traced to the ending of the Civil Rights Movement and the seeds sown for Black militancy. In 1962, Black novelist William Melvin Kelley penned a New York Times article "If You're Woke You Dig It." Kelley's editorial is captioned: "No mickey mouse can be expected to follow today's Negro idiom without a hip assist." Kelley's op-ed begins with him riding a subway train in New York City, reading the various advertisements plastered on the train. One of the advertisements issues from New York Transit Authority, featuring "This is your train, take care of it" in 21 languages. One of the languages is "Beatnik", which puts the following spin on the NYCTA's slogan: "Hey cats this is your swinging-wheels, so dig it and keep it boss." Kelley takes time to note that this language is not Beatnik, but what we have decidedly come to call Black Vernacular English (BVE), the language of Black people from New York City's "No Strings" area to Chicago's South Side. What white and non-Black "users" of Black Vernacular English miss about this variety of English is that it is far from simple. It is about context and inflection, or as Kelley says, "what it means depends on who and what a person is talking about." It hardly be claimed or definite that Kelley's use of "woke" is its genesis; it probably flew from the lips of any anonymous Harlemite. But the importance of "woke" and "stay woke", both as a call for critical consciousness among Black people, and the political purposes of Black speech and utterance, have been missed. Black speech itself is always a form of political consciousness, the counter-hegemonic approach to language which renders its use and dissemination pertinent to calls for Black liberation.

Kelley's article brings the idiom "woke" to print several decades before Badu's song and Childish Gambino's "Redbone." The late writer's definition of "woke" calls for Black political con-

$$
\text { Page } 90
$$

Root Work Journal Vol- 1 Issue- 2 sciousness congeals with its use among 21st century Black musicians and activists. After the Badu track, 'woke' experienced a resurgence in the rhetoric of the Black Lives Matter (BLM Movement. Just as "I have a dream" and gospel lyrics carried the charge of the Civil Rights era, "All Power to the People" bore the militancy of Black Power, "Stay Woke" became aligned with BLM. Beginning with the 2014 murder of Ferguson, Missouri resident Michael Brown, BLM ac tivists began to warn each other to "stay woke." Before its mainstream dilution, "stay woke" ha a history in the rhetoric of Black political organizing and expressive culture. In 1923, President of the United Negro Improvement Association Marcus Garvey harangued his audience with "Wake up, Ethiopia! Wake up, Africa!" Blues musician Lead Belly released a protest song in 1938 titled "Scottsboro Boys" recounting the accusation of rape against nine African American boys in Alabama in 1931. Towards the end of the song Lead Belly sings, "I advise everybody to be a little careful when they go along through there, stay woke, keep their eyes open." African American educator J Saunders Redding takes record of a black United Mines Worker official stating "Let me tell you buddy. Waking up is a damn sight harder than going to sleep, but we'll stay woke up longer" in 1940. These uses predate Kelley's 1962 opinion editorial, and while differing in style, they generally conform to a transnational, Black call-and-response between major Black figures in arts and politics to the broader community of people of African descent. Nevertheless, Kelley's piece and usage of "woke" is notably prescient in his prediction of the absorption and co-optation of Black vernacular into American popular culture. He acknowledges the constant process of transforming the meanings and connotations of Black Vernacular English to keep pace with the culture vultures. And very often, it will be the very same culture vultures calling the death knell on words like "woke." Black breath will distort and contort colonial English into its revolutionary form, and it takes only one ofay to dilute the semantic power of a word. Take for example, columnist David Brooks' 2018 article "The Problem with Wokeness." Then fast forward a few months to NPR contributor Sam Sander's "Opinion: It's Time to Put 'Woke' to Sleep." Sanders' article notes that MTV told people to stop using it in 2016. SNL parodied the slang term's death in 2017. Green Party candidate Jill Stein sent a tweet out to her followers in 2016, accompanied by a graphic reading "Get Woke, Stay Woke." Key to Kelley's article is the function of Black Vernacular Englishes (as well as creoles along with French and Spanish pidgins, etc): We are speaking code. The field slave smiling singing what were later called work songs is speaking code. Code functions both to shield the speaker from the judgment of native speakers of colonial languages, like the phenomenon of code switching, but also as a key to Black sociality. In "Language: Teaching New Worlds/New Words", bell hooks Page 91

Root Work Journa Vol- 1 Issue- 2 
riffs upon African slaves' transformation of linguistic matter. Throughout the text, she repeats this line from Adrienne Rich's poem "The Burning of Paper Instead of Children:" "This is the oppressor's language, yet I need it to talk to you." As peoples belonging to the transnational African diaspora, we have been subject to learning colonial tongues. Standard English, bell hooks notes, is not the speech of exile, of a dispossessed and displaced people, but the language of conquest and domination. Conversely, we can say that neither French, Spanish, and Portuguese are the languages of exile. But their re-wording/re-worlding by colonized and/or displaced African peoples results in Black Vernacular Englishes, pidgins, and creoles. Before we visit African slaves' linguistic adaptations to a hostile environment of chattel slavery, we must also account for the loss of language. That is, before people from sub-Saharan Africa were racialized as Black, they were apart of distinct ethnic groups indigenous to continental Africa. The loss of a mother tongue meant the rupture of kinship systems and the disintegration of social identities. hooks provokes us to think about the difficulty of not hearing the "sound of slaughter and conquest" in standard English. The very sound of English itself, she argues, must have been terrifying. The disruption of deep social bonds forged through shared speech was inevitable to the process of transporting Africans to the New World. When we think about how we, as Black people, speak to each other, we imagine new intimacies. hooks argues that Africans must have realized that standard English was a site for possession, using the language to claim a space of resistance. hooks writes, "In the mouths of black Africans in the so-called "New World," English was altered, transformed, and became a different speech. Enslaved black people took broken bits of English and made of them a counter-language" "Language: Teaching New Worlds/New Words", 1994; emphasis mine). The alchemy of Black Vernacular, in this case applied to standard English, occurs through the mutation of a colonial language into different speech. We see this taking place in the phrase "stay woke": "woke" undergoes resemanticization, in which "new meanings have been attached to pre-existing morphs" "Theorizing African American Women's Language: GIRL as a Discourse Marker", 2009) and "stay" implying some form of performativity, or a condition of political consciousness. Diving deeper into the grammatical aspects of Black Vernacular English, "stay woke" embodies the habitual and intensified continuative aspect of BVE. "Stay woke" evokes a habitual and intensified continuative grammatical aspect, meaning that "stay" acts as an adverbial phrase which strengthens the meaning of "woke", that is, being "woke" represents an action that is ongoing. The grammars of BVE point to the timelessness of anti-blackness, the notion that we are still in the hold of the ship be it on street corners or at Jyy League universities.
We can understand the statement "stay woke" as an alternative temporal state, in which Black people are perpetually aware of the state of the world - localized in the American settler-colonial state wherein the condition of Black social death is always already reality. The potency of Black Vernacular English does not merely lie in its ability to enable resistance to white supremacy, but "that it also forges a space for alternative cultural production and alternative epistemologies - different ways of thinking and knowing that were crucial to creating a counter-hegemonic worldview" ("Language: Teaching New Worlds/New Words", 1994; emphasis mine) It is fruitful to elevate being woke, or "wokeness" to the level of an different way of thinking and knowing the world. If you're woke, you dig it. Emblematic of most black cultural production, however, non-Black people began to use woke. The term is another tragedy of digital blackface: everyone "sounds black" online. As Black radicals continue to fight for our liberation, the value of trying to keep Black cultural production and BVE from use by non-Black people may seem futile and insignificant. But how will we, as Black people, talk to each other? What potential kinship structures and intimacies are disrupted when it is easy for anyone to sound and talk black? I have come to this determination: Black vernacular English should be our property. But it is difficult for the descendants of slaves, who were considered property, to now claim any property. From ridicule over a perceived corruption of colonial languages by Black Americans, to the now popular blaccent occurring IRL and in digital spaces, we may wonder if imitation is the highest form of flattery. Imagine an effective Underground Railroad where all the slavemasters knew exactly what "stations" meant. You would still be on that plantation. Now, we face the unlimited access to Black cultural production, the bodies of Black people, and the representation of the Black image. In 2014, hosted by Critical Resistance, Robin D.G. Kelley and Fred Moten convened over the topic "Do Black Lives Matter?" As with any discussion of Black Lives Matter, Moten begins with a list of Black people that were then lost to police violence: Eric, Garner, Michael Brown. Knowing that Eric Garner sold "loosies", and that his engagement in this activity was why NYPD approached him in the first place, Moten argues that [Garner] "initiated a new kind of marketplace and another mode of social life." To Moten, it is the alternative mode of social life which was killed, not restricted to Garner's individual tale. Black social life is a threat to the very order that murderers such as Darren Wilson swear to protect. Beginning with a recall of the black deaths which preceded the talk, Fred Moten turns our attention away from the phrase "Black Lives Matter" to the nominative "Black Life." Moten notes that Black life is distinguished by its openness and unfixity - "it can claim anybody." This is true in that Blackness happens to someone, and as the phenomenon of Blackfishing tells us, white people are choosing to hapPage 93

Root Work Journal Vol- 1 Issue- 2 
pen to be Black. Rachel Dolezal, Jessica Krug, other white women whose names I can't remember but whose actions will always be salient. I would have never known that this fiction I live would be so palatable to white women. Nevertheless, the fact that Black social life can claim anybody does not mean it can claim those who are not racialized as Black. Black social life,

or Black sociality, has been the historical phenomenon of enacting an alternative way of life, with BVE asking us to imagine new ways of life through language. As Robin D.G. Kelley puts it, the psychic life of America is dependent on Black labor even if it does not value Black life. This reverberates, I think, with this summer's calls to consume the work of Black intellectuals through following anti-racist reading lists, and to buy Black. Only by continuing to produce are Black people valuable, even if our value is not possessed by us. So, black (intellectual) (economic) (entrepreneurial) labor matters, but not necessarily Black life. If you're woke, you can dig it. So, here we are, it is 2020, I am at an American academic institution whose valuing of Black life extends to an essentially accumulative process, following chattel slavery. The university needs more diversity, therefore more Black bodies. Mo Black Bodies, Mo Problems. Mo Money, Mo Problems. You walk past a car with a BLM bumper sticker. You scroll through Twitter and Instagram, peeping bios newly adorned with "BLM. ACAB." White people are still afraid to make eye contact with you. You wonder at what point you became a person of color instead of a Black person. You yearn for that comfort of being around a bunch of Black people, maybe woke, maybe not, but at least they know the disruption of space the Black body causes somewhere inside of them. It is the mass of Black people that is exactly what threatens the order police protect. We, are on the corners, we, are up to no good, we, were seen fleeing from this crime scene, we, gathered together in that neighborhood. Preaching to the converted, you notice that everyone is woke now. Neologisms such as "woke culture" and "woketopians" have been touted out by the Right and Left alike. "Stay woke" has been used ironically, referring to things of minor consequence to Black political consciousness. It is now a term of derision, subject to memeification. Maybe we will create another word signifying Black political awareness, maybe it will be adopted by nonBlack people in a series of weeks. Everyone is woke now, they have read Audre Lorde and "White Fragility" and they know the minute a spectacular black death occurs. We have completed a lesson in morality maybe, or an exercise of empathy. The goal could be just recognizing that Black people are human. Again, I ask and will probably receive no response what does it mean to be human? Do we want to be assimilated into human rights discourse? Do we want to settle for being human? Fred says Black social life imagines and enacts another future. I have no interest in being absorbed into America or following Sylvia Wynter, proving Page 94

\section{Root Work Journal}

Vol- 1 Issue- 2 that Black people can embody the economic principles that govern the current genre of human. As we scramble for the crumbs of BVE after it has been digested by global consciousness, plot to be included in the definition of human, and hope to be the beneficiaries of anti-racist action, what is salvageable? Not my life. Before I live, I am dead. In the case of "stay woke", BVE points to the ontological condition of the Black diaspora: If one isn't sleeping, are they dead? If you're woke, you can dig it. 